\title{
THE ROLE OF CULTURAL CAPITAL IN PRODUCING GOOD HEALTH: A PROPENSITY SCORE STUDY VPLIV KULTURNEGA KAPITALA NA ZDRAVJE: ŠTUDIJA NAGNJENJA
}

Tanja Kamin'1, Ana Kolar'1, Peter M. Steiner²

Prispelo: 29. 10. 2012 - Sprejeto: 23. 1. 2013

Original scientific article

UDC 614:316.334

\begin{abstract}
Introduction: Following Bourdieu's concept of capital, the paper discusses how different states of cultural capital (institutionalised, incorporated and objectified) affect health capital.

Methods: The effect of cultural capital on self-assessed health is estimated with a propensity score matching approach using observational data from the "Media consumption, class and cultural stratification " survey. The survey was conducted in 2010 and covered the adult population in the two biggest cities in Slovenia: Ljubljana and Maribor $(n=$ 820). The analyses investigate whether and how different states of cultural capital affect self-assessed health, and whether there are gender differences in how cultural capital affects self-assessed health.

Results: Cultural capital has a positive effect on health: persons with high cultural capital report a better selfassessed health than persons with low cultural capital. All states of cultural capital (institutionalised, objectified and incorporated) have a significant positive conditional effect on self-assessed health for women, but for men only the overall cultural capital has a significant positive effect.
\end{abstract}

Conclusions: Cultural capital is an important resource for gaining and maintaining good health and can be seen as a source of (in)equities in health.

Key words: health inequalities, cultural capital, education, gender, health, propensity score, Slovenia

Izvirni znanstveni članek UDK 614:316.334

\section{Izvleček}

Uvod: Prispevek razpravlja o vplivu različnih oblik kulturnega kapitala (institucionalnega, objektiviranega in utelešenega) na samooceno zdravja.

Metode: Vpliv kulturnega kapitala na zdravje je ocenjen z metodo nagnjenja in temelji na anketnih podatkih raziskave »Medijska potrošnja, razred in kulturna stratifikacija (2010)«. Vzorec za analizo sestavlja 820 oseb, starih med 18 in 75 let, s stalnim prebivališčem v Mestni občini Ljubljana ali Mestni občini Maribor. Analiza proučuje vpliv kulturnega kapitala na samooceno zdravja in preverja, ali se pri tem pojavljajo razlike med spoloma.

Rezultati: Kulturni kapital pozitivno učinkuje na zdravje: osebe z več kulturnega kapitala bolje ocenjujejo svoje zdravje kot osebe z nizkim kulturnim kapitalom. Vse oblike kulturnega kapitala imajo statistično značilen pozitivni učinek na samooceno zdravja pri ženskah, pri moških pa ima statistično značilen pozitivni učinek na samooceno zdravja samo celotni kulturni kapital.

Zaključki: Kulturni kapital je pomemben vir za odpravljanje, vzpostavljanje ali za ohranjanje razlik v zdravju.

Ključne besede: neenakosti v zdravju, zdravje, kulturni kapital, spol, izobrazba, metoda nagnjenja

\section{INTRODUCTION}

The structural system of social positions determines various interrelated resources that people can use in achieving good health $(1,2)$. The more material, social and cultural resources people have, the better their health should be and vice versa (3-7). Although knowledge and skills, which are both part of cultural 
resources, can be seen as a precondition for most individual action and a key component in people's capacity for agency in the field of health (8), cultural resources have been - in comparison to material and social resources - the least studied in the production of health-related outcomes and the (re)production of health inequities $(1,2,9)$. In empirical studies, the influence of cultural capital has been primarily measured so far through the influence of formal education on health practices and health outcomes. There is an agreement that more education indicates better health and vice versa, although there are various factors (i.e. gender, ethnicity, race, material standard) that alter the association between education and health (10, 11). In addition to formal education, there are other cultural resources that can affect health: they might even compensate for a lack of formal education and/ or influence the transformation of formal education into health capital.

In this article, we investigate how a person's cultural capital, of which formal education is just one of several cultural resources, might affect a person's selfassessed health, which is a good subjective measure for the (objective) health status (12). We conceptualize cultural capital according to the theory of the French sociologist Pierre Bourdieu (13), who operationalises cultural capital in three mutually dependent states: (I) institutionalised cultural capital, which represents formal education and qualifications, (II) incorporated cultural capital, which stands for embodied knowledge, cognitive abilities, skills, taste and competencies, and (III) objectified cultural capital, which represents material forms and representations of knowledge, social recognition and cultural goods. They all carry a particular meaning based on systems of social values and norms and are understood as the productive elements of a society's broader system of social distinction (1). »In modern affluent societies, where the basic standard of living secures survival (incl. basic medical care) for almost all its members, the relative importance of non-material resources for health and well-being increases /.../ under conditions /.../ such as the widening of consumer choices for many and the increasing importance of information processing for the successful management of everyday life, the role of cultural factors for the production of good health is ever increasing « (1). Cultural capital does affect health, not only through lifestyles and everyday health related practices, but it has a prominent role in shaping the content and tone of health care encounters and thus enables the (re)production of social inequalities in patient-provider interactions. Shim even coined the term »cultural health capital« to describe a specialized form of cultural capital: particular behaviour, characteristics and competencies that are recognised as assets and can be leveraged in health care contexts to effectively engage with medical providers in clinical interactions (9). Why do we perceive that education alone is not a sufficient indicator for evaluating the potential effect of cultural capital on health? Firstly, education is, as Bourdieu informs us, only one state of a person's cultural capital, which can be effectively transformed into other types of capital such as economic and social capital (13). Secondly, formal education as an asset per se cannot be utilised equally well by different groups of people. In Slovenia, education contributes to reduced depression levels among both genders; however, its influence is substantially higher among women. Loweducated women show a significantly higher depression score than low-educated men, yet highly-educated women show better mental health than highly-educated men (11). Furthermore, African-Americans in the United States, for example, are less able than whites to convert their educational assets into years of healthy life (14). Thirdly, formal education does not play the same role in all socio-economic circumstances. The transformative power of education as a capital into other types of capital depends on its value on the market (13). In Slovenia, for example, researchers have noticed a rapid increase in higher education. With an increasing number of higher educated people, the social status of higher education is decreasing because it no longer presents a competitive value in the overall social distinction processes. In other words, higher education is "a must", but at the same time not a guarantee for better chances to get the best jobs on the market. The decision to enter higher education is thus no longer only the result of personal preferences for outstanding achievements and greater independence. Prolonged education is, particularly among women, also a consequence of lacking options in the labour market $(11,15)$. Thus, education might lose its direct effect on health because education alone does no longer guarantee improved life chances. Finally, in late modern societies, people gain knowledge, skills and competencies in several non-formal educational settings. It is very likely that informal learning will increase in importance and thus add to a person's competitive advances in the market.

\subsection{Research questions and the aims of the study}

The main research questions of our study are: (I) How do different states of cultural capital (i.e., institutionalised, objectified and incorporated) affect self-assessed 
health? (II) Do objectified and incorporated cultural capital affect self-assessed health if we condition on institutionalised cultural capital, i.e., on education levels (i.e., do objectified and incorporated cultural capital explain something in addition to institutionalised cultural capital)? (III) Is there a difference between women and men in how cultural capital affects their self-assessed health?

This study aims to: (I) enrich the debate on health resources and the reproduction of health inequities by investigating how different states of cultural capital might affect self-assessed health; (II) evaluate the link between different states of cultural capital and selfassessed health using propensity score matching, which is one of the most advanced statistical methods for inferring causal effects and conditional associations from studies with observational data. To the best of our knowledge, propensity score methods have never been used before to evaluate how cultural capital affects self-assessed health.

\section{METHODS}

Propensity score methods have primarily been used for estimating causal treatment effects from observational studies (24). However, propensity score methods can also be used for observational studies where the nature of the collected data does not support the estimation of a treatment's causal effect. For instance, when the onset of treatment is not clearly defined (i.e., the treatment does not represent an actively controlled intervention) or when the temporal precedence of the measured covariates is unclear (i.e., covariates that are measured during or after the treatment and, thus, might have been affected by the treatment). In these cases, we cannot estimate causal treatment effects but only associational effects conditional on some substantively interesting covariates. In order to investigate the conditional effects of cultural capital states on self-assessed health, we pursue a propensity score (PS) matching strategy. PS matching creates two groups of respondents - one with high cultural capital, the other with low cultural capital - that are as similar as possible in the substantively interesting covariates and only differ with respect to their cultural capital status. It is important to note that matching is performed without looking at the outcome variable (i.e., self-assessed health is out of sight until the cases have been matched). Only after we have obtained comparable groups (i.e., a study design with balanced covariate distributions), the conditional effect of cultural capital on self-assessed health is estimated.
Thus, PS matching has clear design advantages over ordinary-least-square methods where covariate imbalances cannot be controlled without using the outcome variable. Moreover, unlike regression analysis, PS matching does not rely on functional form assumptions and extrapolation; the effects of cultural capital states on self-assessed health are estimated only from comparable (matched) cases. We use optimal full matching for our analyses, which exhausts the complete dataset and allows a direct estimation of conditional associations between cultural capital and self-assessed health.

\subsection{Data}

The data for our analysis was collected within the research project Culture and class (16) between December 2009 and February 2010. The target population is adults aged 18 years or older with a permanent address in either Ljubljana or Maribor. Units were randomly sampled from the Central Population Register of Slovenia. Simple random sampling was used for this type of population as recommended by the Slovenian Statistical Office based on the prior experience of their sampling professionals. 820 faceto-face interviews were successfully completed. $49 \%$ of the respondents were men and $51 \%$ were women; 408 respondents were from Ljubljana and 412 from Maribor. $19 \%$ of the respondents were younger than 30 years, $1 / 3$ were between 31 and 45 years old, $30 \%$ were between 46 and 60 years old, and $21 \%$ of the respondents were older than 60 years. The collected data has been weighted based on gender and age via poststratification adjustment using the raking method. The survey data consist of 105 variables. For our analyses, we selected three types of variables: (I) self-assessed health as our dependent variable - its relationship with morbidity and mortality is wellresearched and proves a good measure for the health status: self-assessed poor health is related to a higher risk of poor health outcomes (i.e., higher mortality and morbidity) (12); (II) variables related to cultural capital states in order to construct cultural capital indexes; and (III) variables that serve as covariates for balancing group differences between units belonging to different cultural capital levels (low vs. high). The ten variables that we selected to control for group differences are related to both self-assessed health and the cultural capital states and are as follows: the respondent's gender, age and nationality, the job of the respondent's father when the respondent was 15 years old, the education of respondent's father, the job of the 
respondent's mother when the respondent was 15 years old, the education of respondent's mother, the political party to which the respondent relates, the political orientation (i.e., left, right, middle) and the residence location (i.e., Maribor, Ljubljana). We decided not to include further covariates like income or social class because they might have been causally determined by the respondent's health status or one of the cultural capital variables, leading to the problem of reverse causation. Conditioning on these kinds of covariates might actually remove some of the conditional effect that is attributable to cultural capital.

Because we are aiming to investigate different aspects of the effect of cultural capital on self-assessed health, we constructed three different cultural capital indexes: objectified, incorporated and overall cultural capital. The variables used to create the three indexes were selected according to Bourdieu's theory (13). The institutionalised cultural capital includes only one variable - education, which denotes the highest educational degree attained. The objectified cultural capital index includes 6 variables - the possession of a number of: (I) books, (II) original music LPs and CDs, (III) Music in mp3 format, (IV) original Art, (V) possession of a PC (yes/no) and (VI) access to an Internet connection (yes/no) in the household. According to the theory, these variables represent material forms and are representations of knowledge, social recognition and cultural goods. The incorporated cultural capital index includes 3 variables: (I) self-reported foreign language skills (English, ExYugoslavian, Other), (II) self-assessed competencies of Internet use (scale from 1 to 7 ), and (III) self-assessed knowledge of art (five levels of agreement: I don't agree at all, I don't agree, neither-neither, I agree, I completely agree). All these variables are intrinsic to a person; they present the embodied knowledge, perceptions, cognitive abilities, skills and competencies. The overall cultural capital index consists of all the variables included in the incorporated and objectified cultural capital index, and the institutionalised cultural capital. Some observations in our data set were missing due to item-nonresponse. However, none of our variables contained more than $10 \%$ missing values. The majority of variables had less than $5 \%$ missing values. We imputed the few missing values in our data set using chained equations as implemented in the R-package mice (17), which uses linear regression for continuous variables, logistic regression for dummy variables and polytomous regression for discrete variables with more than 2 levels.

We constructed the objectified, incorporated and cultural capital indexes by first transforming all the continuous variables to a zero-to-one scale (with a minimum of 0 and maximum of 1) and then by taking the average value of all the variables included in the index. For each continuous index, we then created a dummy variable indicating a low vs. high cultural capital status where the cut-off point was defined by the median value of each index, respectively. We used these dichotomous cultural capital variables as dependent variables for estimating propensity scores. Table 1 shows the mean values and standard deviations for low and high levels of cultural capitals as well as standardised mean differences, which indicate the difference between the two groups in terms of the underlying continuous indexes. As we can see, by switching from low to high cultural capital, for example, there is a shift of 1.49 standard deviations (SD) in objectified cultural capital. This information helps in interpreting the effects of cultural capital on selfassessed health presented later in Tables 2, 3 and 4.

Table 1. The descriptive statistics for objectified, incorporated and overall cultural capital (CC).

Tabela 1. Deskriptivna statistika za objektiviran, utelešen in skupni kulturni kapital (KK).

\begin{tabular}{|l|l|l|l|l|l|}
\hline & Mean - low & SD - low & Mean - high & SD - high & $\begin{array}{l}\text { Standardised } \\
\text { mean } \\
\text { difference }\end{array}$ \\
\hline $\begin{array}{l}\text { Objectified CC / } \\
\text { objektiviran KK }\end{array}$ & 0.24 & 0.15 & 0.50 & 0.07 & 1.49 \\
\hline $\begin{array}{l}\text { Incorporated CC/ } \\
\text { utelešen KK }\end{array}$ & 0.34 & 0.11 & 0.62 & 0.09 & 1.64 \\
\hline $\begin{array}{l}\text { Ove rall C C/ } \\
\text { skupni KK }\end{array}$ & 0.30 & 0.12 & 0.60 & 0.09 & 1.63 \\
\hline
\end{tabular}

Note: SD - standard deviation 
The institutionalised cultural capital is represented by the three-valued education variable: (I) a low educational level (11 or fewer completed schooling years) (II) a middle education level (between 12 and 14 completed schooling years) and (III) a high education level (15 and more completed schooling years). The self-assessed health variable consists of 5 levels: (I) very poor, (II) poor, (III) satisfactory, (IV) good and (V) very good. In our analyses, we used self-assessed health as a continuous variable ranging from 1 to 5 with a mean of 3.69 and a standard deviation of 0.95 .

\subsection{Propensity score study}

In order to balance the study design and obtain comparable cultural capital groups on the observed covariates (i.e., the 10 covariates that were selected) we first estimated, for each cultural capital index, the respondents' propensities for being in the high vs. low

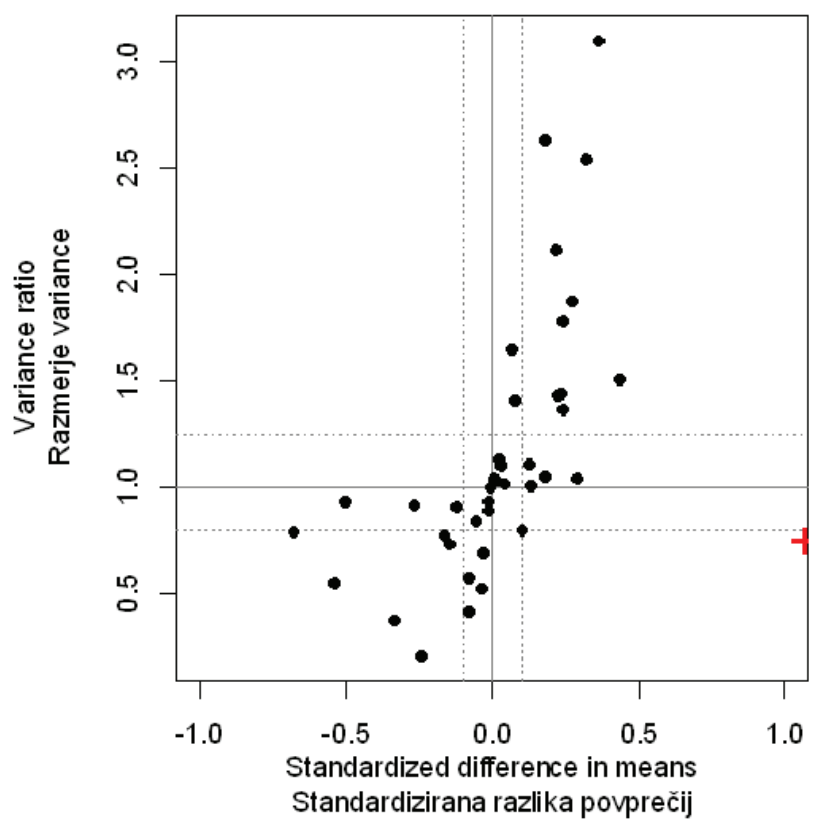

group (for the three-valued education variable, we estimated the propensity scores for all three group comparisons). We estimated the propensity scores using logistic regression. For example, the PS model for the objectified cultural capital (OCC) indicator was specified as follows:

$\operatorname{logit}(\mathrm{OCC})=\beta_{0}+\beta_{1} \mathrm{sex}+\beta_{2}$ age $+\beta_{3}$ nationality + $\beta_{4}$ father's work $+\beta_{5}$ father's education + $\beta_{6}$ mother's work $+\beta_{7}$ mother's education + $\beta_{8}$ political party $+\beta_{9}$ political orientation + $\beta_{10}$ respondent's location $+\beta_{11}$ age $*$ mother's work + $\beta_{12}$ Sex $*$ political party $+\beta_{13}$ location $*$ political party

As model-specification criteria, we used the balance in the observed covariates (18). An example of a balance plot is presented in Figure 1.

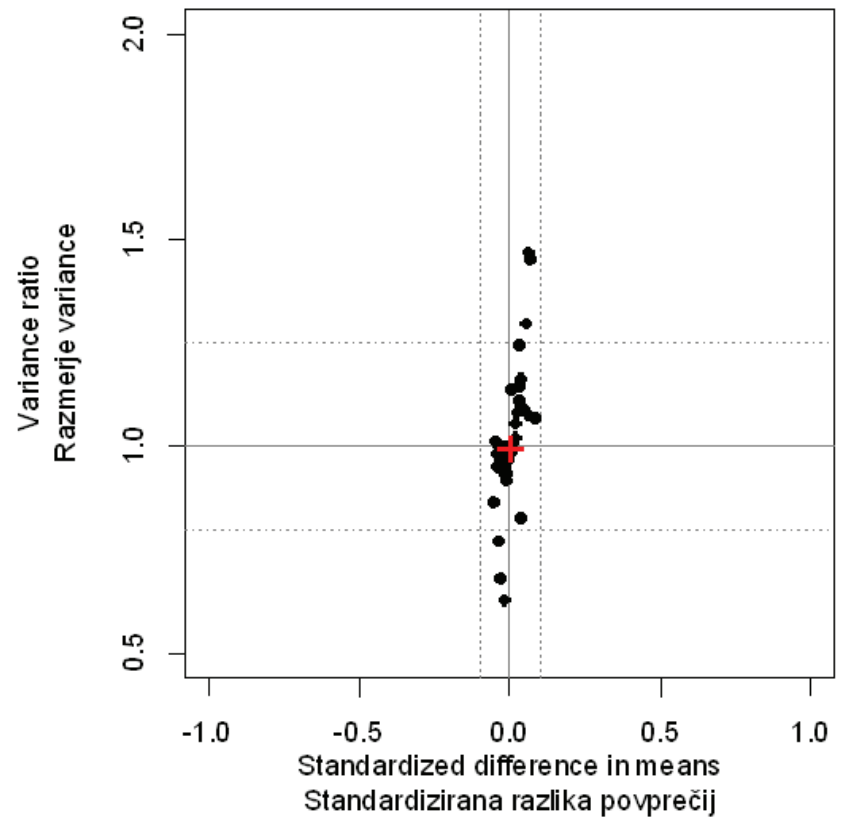

Figure 1. Balance plots for objectified cultural capital: the initial imbalance in the observed covariates (left plot) and the balance in the observed covariates after matching (right plot). Categorical variables are included as dummies.

Slika 1. Graf usklajenosti za objektiviran kulturni kapital: začetna neusklajenost v kovariatah (levi graf) in usklajenost $v$ kovariatah (desni graf). Kategorialne spremenljivke so slepo kodirane.

The left plot in Figure 1 shows that, before matching, the respondents in the high and low objectified cultural capital (CC) group differ considerably in several observed covariates, potentially resulting in a biased effect estimate of objectified CC on self-assessed health. After matching the respondents with low and high objectified CC on the estimated logit of the PS (we used optimal full matching with a calliper of $0.1 \mathrm{SD}$ (19)), nearly all the covariate differences between the low and high objectified CC group have been removed (right plot in Figure 1). All the standardised mean differences are close to zero (within $0.1 \mathrm{SD}$ ) and, for 
most covariates, the variance ratios between the low and the high objectified CC group are within $4 / 5$ and 5/4. Thus, the plot indicates a good balance in the observed covariates. The estimated PSs for the other cultural capital indexes established a similarly good balance on the observed covariates in the matched data set for each of our studies. Finally, we estimated the conditional effects of cultural capital on self-assessed health using a weighted least-squares regression:

Self-assessed health $=\beta_{0}+\beta_{1}$ cultural capital state + $\beta_{2}$ location $+\beta_{3}$ sex $+\beta_{4}$ age $+\varepsilon$

with individual case weights derived from the matching structure. We included covariates sex, age and residence location (i.e., Maribor, Ljubljana) in order to remove residual imbalances (i.e., the imbalances left after matching) and to increase the efficiency of our estimates.

\section{RESULTS}

\subsection{Conditional associations between different states of cultural capital and self-assessed health}

Table 2 presents the conditional association between self-assessed health and (I) different levels of institutionalised capital (estimates refer to comparisons of low vs. high education level, low vs. medium education level and medium vs. high education level), (II) the dichotomous objectified cultural capital index, (III) the dichotomous incorporated cultural capital index, and (IV) the dichotomous overall cultural capital index.

Table 2. Conditional effect estimates for the different cultural capital (CC) indexes on self-assessed health. Tabela 2. Ocene pogojnih učinkov različnih indeksov kulturnega kapitala (KK) na samooceno zdravja.

\begin{tabular}{|c|c|c|c|c|c|}
\hline & Estimate & $\begin{array}{l}\text { Std. } \\
\text { Error }\end{array}$ & $p$-value & $n$ & $\begin{array}{l}\text { Preserved } n \\
\text { (effective } n \text { ) }\end{array}$ \\
\hline $\begin{array}{l}\text { Low vs. high institutionalised CC/ } \\
\text { nižji vs. višji institucionalizirani KK }\end{array}$ & 0.44 & 0.09 & 0.000 & 419 & $\begin{array}{l}70.64 \% \\
(\mathrm{n}=295)\end{array}$ \\
\hline $\begin{array}{l}\text { Low vs. medium institutionalised CC / } \\
\text { nižji vs. srednji institucionalizirani KK }\end{array}$ & 0.19 & 0.07 & 0.006 & 620 & $\begin{array}{l}93.4 \% \\
(n=579) \\
\end{array}$ \\
\hline $\begin{array}{l}\text { Medium vs. high institutionalised CC / } \\
\text { srednji vs. višji institucionalizirani KK }\end{array}$ & 0.11 & 0.07 & 0.120 & 599 & $\begin{array}{l}88.16 \% \\
(n=528) \\
\end{array}$ \\
\hline $\begin{array}{l}\text { Objectified CC / } \\
\text { Objektivirani KK }\end{array}$ & 0.21 & 0.06 & 0.000 & 819 & $\begin{array}{l}96.1 \% \\
(n=787) \\
\end{array}$ \\
\hline $\begin{array}{l}\text { Incorporated CC / } \\
\text { Utelešeni KK }\end{array}$ & 0.06 & 0.06 & 0.37 & 819 & $\begin{array}{l}87.2 \% \\
(n=714) \\
\end{array}$ \\
\hline $\begin{array}{l}\text { Cultural capital (institutional + } \\
\text { objectified + incorporated CC) (CC)/ } \\
\text { Kulturni kapital (institucionalizirani + } \\
\text { utelešeni + objektivirani) }\end{array}$ & 0.36 & 0.06 & 0.000 & 819 & $\begin{array}{l}88.5 \% \\
(n=724)\end{array}$ \\
\hline
\end{tabular}

The first investigation with respect to the effect of the different levels of institutionalised CC on self-assessed health shows significant positive effects for the low vs. high contrast and the low vs. medium contrast and a positive but insignificant effect for the medium vs. high contrast. This means that an individual with a higher institutionalised CC assesses his/her health as being better than an individual with a lower level of institutionalised CC. The objectified CC has a significant positive effect (0.21) on the self-assessed health of an individual. Individuals that possess a more objectified CC on average assess their health better than individuals with a less objectified CC. However, from a subject-matter point of view, the average 0.21 
increase on the 5-point scale of self-assessed health represents only a moderate effect given that the contrast between the low and high objectified CC status is rather strong (1.49 SD) as Table 1 shows; the 0.21 increase translates into an effect size of 0.15 standard deviations). The incorporated CC has a very small positive but insignificant effect on self-assessed health. The overall CC, which includes all three states of CC (i.e., institutionalised, objectified and incorporated), has a significant positive effect $(0.36)$ on self-assessed health. Individuals that possess more CC are thus likely to assess their health as better than individuals with less CC. However, from a subject-matter point of view, the average increase of 0.36 on the 5-point scale of self-assessed health represents only a moderate effect (effects size of $0.23 \mathrm{SD}$ ) since the contrast between the low and high CC status is rather strong (1.6 SD as Table 1 shows).

\subsection{The conditional association between cultural capital (i.e., objectified and incorporated, respectively) and self-assessed health within each level of institutionalised cultural capital}

The previous section presented the conditional effects of different states of cultural capital (CC) on self-assessed health. However, the positive effects of objectified CC and incorporated CC on self-assessed health might be due to the correlation of objectified and incorporated CC with institutionalised CC rather than the objectified and incorporated CC on their own. Therefore, the second study controls for the institutionalised CC when estimating the conditional association between objectified CC and self-assessed health, and between incorporated CC and self-assessed health. We used a stratification approach where we conducted a separate PS analysis via optimal full matching in each of the three levels of institutionalised CC.

Table 3. Objectified and incorporated cultural capital (CC) investigated within each level of institutionalised CC. Tabela 3. Objektivirani in utelešeni kulturni kapital (KK) glede na ravni institucionaliziranega KK.

\begin{tabular}{|l|l|l|l|l|l|}
\hline & Estimate & $\begin{array}{l}\text { Std. } \\
\text { Error }\end{array}$ & $p$-value & $n$ & $\begin{array}{l}\text { Preserved } n \\
\text { (effective } n)\end{array}$ \\
\hline $\begin{array}{l}\text { Low institutionalised CC level - objectified CC/ } \\
\text { Nizka raven institucionaliziranega KK - } \\
\text { objektivirani KK }\end{array}$ & 0.18 & 0.14 & 0.20 & 220 & $67.7 \%(n=148)$ \\
\hline $\begin{array}{l}\text { Medium institutionalised CC level - objectified } \\
\text { CC/ } \\
\text { Srednja raven institucionaliziranega KK - } \\
\text { objektivirani KK }\end{array}$ & 0.13 & 0.07 & 0.08 & 400 & $91.75 \%(n=367)$ \\
\hline $\begin{array}{l}\text { High institutionalised CC - objectified CC/ } \\
\text { Višja raven institucionaliziranega KK - } \\
\text { objektivirani KK }\end{array}$ & 0.22 & 0.15 & 0.15 & 199 & $61.8 \%(n=122)$ \\
\hline $\begin{array}{l}\text { Low institutionalised CC level - incorporated CC / } \\
\text { Nizka raven institucionaliziranega KK - utelešeni } \\
\text { KK }\end{array}$ & 0.27 & 0.15 & 0.07 & 220 & $67.2 \%(n=147)$ \\
\hline $\begin{array}{l}\text { Medium institutionalised CC level - incorporated } \\
\text { CC / } \\
\text { Srednja raven institucionaliziranega KK - } \\
\text { utelešeni KK }\end{array}$ & 0.20 & 0.08 & 0.01 & 400 & $89.3 \%(n=357)$ \\
\hline $\begin{array}{l}\text { High institutionalised CC level - incorporated } \\
\text { cultural capital / } \\
\text { Višja raven institucionaliziranega KK - utelešeni } \\
\text { KK }\end{array}$ & -0.07 & 0.13 & 0.60 & 199 & $82.9 \%(n=164)$ \\
\hline
\end{tabular}


When stratifying on the levels of institutionalised $\mathrm{CC}$, the estimated conditional effects of objectified $\mathrm{CC}$ and incorporated CC on self-assessed health are not significant, with the exception of the effect of incorporated CC for the medium and perhaps the low level of institutionalised CC. It should be noted that the sample size in this analysis (Table 3 ) is smaller, which might have affected the significance. Nonetheless, the pattern of results across the three levels of institutionalised CC suggests that objectified CC could positively affect self-assessed health in addition to institutionalised CC. Furthermore, in comparison to the insignificant effect of incorporated CC on self-assessed health of 0.06 of the un-stratified analysis (Table 2), this analysis suggests that incorporated $\mathrm{CC}$ has a positive association with self-assessed health but only for persons with a medium and perhaps for persons with a low level of institutionalized CC.

\subsection{Gender-specific analysis of conditional associations between different states of cultural capital and self-assessed health, respectively}

We performed a separate PS analyses for women and men in order to investigate whether the strength of conditional associations between the different cultural capital indexes and self-assessed health differ between women and men.

Table 4. Conditional effect estimates of objectified, incorporated and overall cultural capital (CC) and selfassessed health with regard to gender.

Tabela 4. Ocene pogojnih učinkov objektiviranega, utelešenega in celotnega kulturnega kapitala (KK) na samooceno zdravja glede na spol.

\begin{tabular}{|c|c|c|c|c|c|}
\hline & Estimate & Std. Error & $p$-value & $\mathrm{n}$ & $\begin{array}{l}\text { Preserved } n \\
\text { (effective } n \text { ) }\end{array}$ \\
\hline $\begin{array}{l}\text { Women - overall CC/ } \\
\text { Ženske - KK }\end{array}$ & 0.34 & 0.08 & 0.000 & 450 & $74 \%(n=333)$ \\
\hline $\begin{array}{l}\text { Man - overall CC/ } \\
\text { Moški - KK }\end{array}$ & 0.23 & 0.10 & 0.015 & 369 & $81,6 \%(n=301)$ \\
\hline $\begin{array}{l}\text { Women - objectified CC/ } \\
\text { Ženske - objektivirani KK }\end{array}$ & 0.21 & 0.08 & 0.008 & 450 & $91 \%(n=409)$ \\
\hline $\begin{array}{l}\text { Men - objectified CC/ } \\
\text { Moški - objektivirani KK }\end{array}$ & 0.16 & 0.09 & 0.08 & 369 & $79 \%(n=291)$ \\
\hline $\begin{array}{l}\text { Women - incorporated CC/ } \\
\text { Ženske - utelešeni KK }\end{array}$ & 0.19 & 0.08 & 0.02 & 450 & $90 \%(n=405)$ \\
\hline $\begin{array}{l}\text { Men - incorporated CC/ } \\
\text { Moški - utelešeni KK }\end{array}$ & -0.08 & 0.08 & 0.37 & 369 & $90 \%(n=332)$ \\
\hline
\end{tabular}

Table 4 indicates that the conditional effect estimates of different states of $\mathrm{CC}$ on self-assessed health for women are positive and significant. For males, only the effect of the overall CC and self-assessed health is significantly positive whereas the effects of the other two states of CC, the objectified CC and the incorporated $\mathrm{CC}$, are insignificant. The gender-specific analysis within each level of institutionalised CC was not feasible; Due to the small sample sizes we could not obtain a balanced design (i.e., comparable groups).

\section{DISCUSSION}

The results of our analyses confirm the thesis that cultural capital (CC) is positively associated with self-assessed health: persons with a high CC assess their health better than persons with a low CC. CC and particular states of CC, namely objectified and incorporated CC, have a significant positive conditional effect on self-assessed health for women, but only the overall CC has a significant conditional positive effect 
for men. These results indicate that $\mathrm{CC}$ affects the selfassessed health of women stronger than of men. This has only been confirmed by previous research (11) for institutionalised CC. Thus, women seem to be more successful than men in transforming $\mathrm{CC}$ related assets into health-related resources.

For the overall population of women and men, institutional CC seems to have a stronger conditional effect on self-assessed health than objectified and incorporated CC. The positive differences in selfassessed health between medium and low, and high and low levels of institutionalised CC are in accordance with previous findings $(20,21)$ suggesting that formal education is still of significant importance for life opportunities, and thus constitutive of class positions. Higher educational levels are therefore positively related to life opportunities and, consequently, positively related to health. According to previous analyses of the same data (22), people with a low education use their overall material position and possibilities to decide on their course of life less effectively than people with a high education. Low-educated people have lower aspirations and feel rather trapped in the situation they are in. Thus, they have the fewest resources that can be transformed into other capitals, including health. Furthermore, our analyses showed a small difference in self-assessed health between the medium and high levels of institutionalised CC. One possible interpretation is that differences in life opportunities between Slovenians with a medium and a high formal education are rather small since all medium- and high-educated persons mainly belonged to the middle class, which has been characterized by small differences in socioeconomic positions and aspirations, automatic access to good public schooling, easily accessible public health care and other social services (23). These were all remnants of the socialistic welfare state's social policies, which Slovenia built on after it became an independent state. Social equality has been an important value, and social policies were formed in this regard: all citizens, regardless their socio-economic status should have equal opportunities in achieving good education, health care and social support. The cornerstones of these social policies have been deteriorating recently; they are becoming less socially inclusive. Consequently, the relatively small differences in health status among the Slovene population might gradually disappear.

Incorporated CC has a significant yet small positive conditional effect on self-assessed health among women. According to the theory, the incorporated CC represents embodied knowledge, cognitive abilities, skills, taste and competencies, which are resources with a high potential for being transformed into health capital. For women and men together, the conditional effect of the incorporated CC on health is positive but only statistically significant for the medium educational level. The general insignificance of the conditional effect of the incorporated CC on self-assessed health might be due to the relatively small sample size, or our skills and competencies measurements were not the best measurements for the incorporated CC. Also, it is possible that respondents do not (yet) largely use the measured skills and competencies as resources for improving their health. Nevertheless, the pattern of results suggests that the lower a person's institutionalised CC is, the greater the effect of the incorporated CC on health. This could suggest that in order to gain better health, the incorporated CC can compensate for the lack of the institutionalised CC if structural circumstances allow it. For example, competence in using the internet enables people to access relevant health-related information; this can facilitate better health related decisions and lead to more effective and credible participation in health care encounters. Furthermore, a higher incorporated CC can enable individuals to more effectively utilize the existing social structures in health-promoting ways. Our analyses show that women might be more successful at transforming these cultural resources into health capital than men. We expect that incorporated CC might have a greater role in the future because people - as consumers of health - are required to more actively participate in health-related decisions, not only in contexts of everyday life but also in clinical interactions. Furthermore, the people in our sample still represent the generation in which good jobs on the market were almost guaranteed for formally well-educated people, but this has now changed. Consequently the incorporated CC might grow in importance in gaining better life chances.

The objectified CC has a significant positive conditional effect on the health status. Individuals that possess more objectified CC assess their health better than individuals with less objectified CC. Our analyses show that this effect is positive and significant, particularly for women. The objectified CC is in theory in close interaction with the incorporated $\mathrm{CC}$ regarding the skills and competencies that people possess to transform cultural artefacts into health-related resources and capital. Having access to the Internet is an important asset, but only if one feels competent using it; books can be used for showing off or as an important source 
of information or therapeutic support; and music can be utilised for stress release. We expect that the objectified $\mathrm{CC}$ might have a greater role in the future, because the technology for self-monitoring health parameters is becoming more developed and widely available. We should also note that the objectified $\mathrm{CC}$ might be related to better material standard and economic status of an individual that significantly affects health status (2). Nevertheless, the analyses suggest that the objectified CC matters in how one assesses their health status; and that women are more skilful than men in utilising the objectified CC for gaining health capital.

\section{CONCLUSIONS}

This article aims to contribute to the discussion about the impact of different states of cultural capital on good health by using propensity score methods, one of the most advanced statistical methods for drawing conditional association inference from observational studies. Knowledge, skills, competencies, cultural artefacts, etc. can be viewed as different types of cultural capital, because they function as resources that can be utilised and transformed in other capitals (economic, social), including health capital. As such they are intrinsically related to the social distinction processes and the (re)production of social inequalities, thus being involved in the unequal distribution of health. Our study supports the initial thesis that cultural capital has a positive effect on health and, in addition, that objectified and incorporated cultural capitals can significantly modify the effect of institutionalised capital on self-assessed health. All states of cultural capital (institutionalised, objectified and incorporated) have a significant positive conditional effect on self-assessed health for women, but only the overall cultural capital has a significant positive effect for men. We expect that the role of incorporated and objectified cultural capital will increase in the future. The take-home message of our study is that cultural capitals should be considered when developing social policies for addressing health equity. Despite similar socio-economic positions, different levels of possessed cultural capitals can be an influential factor in reproducing differences in health status. Investments in cultural capitals could therefore be recognised as an investment in health as well.

Although our results are in line with the theory, there are some limitations to our study. Due to the nature of our data, we are not claiming that the estimated conditional effects are necessarily causal effects. In our analysis, we did not control for variables that might have been affected by the outcome variables or the treatment variables (reverse causation). For example, we decided not to condition on income because a respondent's income is probably also affected by the respondent's health condition. Thus, conditioning on income might have removed parts of the cultural capital effect on self-assed health. Finally, even better conclusions could be reached if we expand the research model and evaluate the effect of cultural capital on self-assessed health in relation to other types of capital as well: social and economic. This could prove a good challenge for further research.

\section{References}

1. Abel T. Cultural capital in health promotion. In McQueen DC, Kickbusch I, editors. Health and modernity. the role of theory in health promotion. Berlin: Springer, 2007: 43-73.

2. Kamin T, Tivadar B. Kapital(i) in zdravje. Teor Praksa 2011; 48: 1028-1047.

3. Friedli L. Reasons to be cheerful: the 'count your assets' approach to public health perspectives. Available September 10, 2011 from: http://democraticleftscotland.wordpress.com/ perspectives/

4. Morgan A, Davies M, Ziglio E, editors. Health assets in a global context - theory, methods, action. London: Springer, 2010.

5. Kawachi I, Kennedy BP, Lochner K, Prothrow-Stith D. Social capital, income inequality, and mortality. Am J Public Health 1997; 87: 1491-1498.

6. Leskošek V. Social determinants of health: the indicators for measuring the impact of poverty on health. Zdrav Var 2012, 51: 21-32.

7. Marmot M, Wilkinson R. Psychosocial and material pathways in the relation between income and health. BMJ 2001; 322: 1233-1236.

8. Abel T, Frohlich KL. Capitals and capabilities: linking structure and agency to reduce health inequalities. Soc Sci Med 2012; 74: 236-244.

9. Shim KJ. Cultural health capital: a theoretical approach to understanding health care interactions and the dynamics of unequal treatment. J Health Soc Behav 2010; 51: 1-15.

10. Suhrcke M, de Paz Nieves $C$. The impact of health and health behaviours on educational outcomes in high-income countries: a review of the evidence. Copenhagen: WHO. 2011. Available September 10, 2012 from: http://www.euro.who.int/_data/ assets/pdf_file/0004/134671/e94805.pdf

11. Kamin T, Berzelak N, Ule M. Vpliv izobrazbe na razlike med spoloma v prisotnosti simptomov depresije v Sloveniji. Zdrav Var 2012; 51: 33-42.

12. Idler EL, Benyamini Y. Self-rated health and mortality: a review of twenty-seven community studies. J Health Soc Behav 1997; 38: 21-37.

13. Bourdieu P. The forms of capital. In: Halsey $\mathrm{AH}$, Lauder $\mathrm{H}$, Brown P, Stuart Wells A, editors. Education: culture, economy, and society. Oxford: Oxford University Press, 1997: 46-58.

14. Crimmins EM, Saito $Y$. Trends in healthy life expectancy in the United States, 1970-1990: gender, racial, and educational differences. Soc Sci Med 2001; 52: 1629-1641.

15. Ule M. Prikrite spolne neenakosti v izobraževalnih potekih in prehodih. Sod Pedag 2010; 61: 30-44. 
16. Luthar B. et al. Medijska potrošnja, razred in kulturna stratifikacija: končno raziskovalno poročilo s sumarnikom. Ljubljana: Fakulteta za družbene vede, 2011.

17. van Buuren S, Groothuis-Oudshoorn K. Mice: multivariate imputation by chained equations. J Statist Software 2011; 45: 1-67.

18. Steiner PM, Cook DL. Matching and propensity scores. In: Little TD, editor. The Oxford handbook of quantitative methods. New York: Oxford University Press, 2013.

19. Hansen BB, Klopfer SO. Optimal full matching and related designs via network flows. J Computat Graph Statist 2006; 15: $609-627$
20. Crompton R. Class and stratification: an introduction to current debates. Cambridge: Polity Press, 2004.

21. Kropivnik S, Luthar B. Class, cultural capital, and the mobile phone. Czech Soc Rev 2011; 47: 507-529.

22. Kamin T, Tivadar B, Kropivnik S. What have Andy Warhol, pekorino and wasabi in common?: food practices in Ljubljana and Maribor. Družboslovne Razprave 2012; 28: 93-111.

23. Malnar B, Kurdija S. Trends in subjective health assessment between 1981 and 2011 as an indicator of persistent social inequalities. Zdrav Var 2011; 51: 11-20.

24. Rosenbaum PR, Rubin DB. The central role of the propensity score in observational studies for causal effect. Biometrika 1983; 70: 41-55. 